\title{
DATA-flow in the field of urban planning: basics, concept, methodology
}

\author{
Pavel Chelyshkov ${ }^{*}$, Sergey Volkov ${ }^{2}$, and Evgeny Babushkin ${ }^{1}$ \\ ${ }^{1}$ Moscow State University of Civil Engineering, 129337, Moscow, Russia \\ ${ }^{2}$ Centre of Expertise for Major Construction Projects, Private Enterprise of the Rosatom State Atomic \\ Energy Corporation, 119180, Moscow, Russia
}

\begin{abstract}
This article discusses the basics, concept and methodology for constructing tools that implement data exchange processes, including an exhaustive list of necessary data for the formation of information models of capital construction objects at each stage of the life cycle, as well as a plan for the development of these tools that provide information exchange processes. The technical and technological foundations for the formation of a digital information model and a scheme for verifying information transmitted from stage to stage of the life cycle of a capital construction object are stated.
\end{abstract}

\section{Introduction}

The increasingly widespread use of information modeling technologies, including at various stages of the life cycle of buildings and structures [1-16], puts on the operational agenda the issue of forming tools for seamless exchange of digital data in information systems to support urban planning activities. The Resolution of the Government of the Russian Federation No. 1431, issued on September 15, 2020, "On approval of the Rules for the formation and maintenance of an information model of a capital construction object, the composition of information, documents and materials included in the information model of a capital construction object and presented in the form of electronic documents, and requirements for the formats of these electronic documents, as well as amending clause 6 of the Regulation on the performance of engineering surveys for the preparation of design documentation, construction, reconstruction of capital construction facilities "[17], prescribes the formation of data exchange tools in the form of XML-schemas. This approach provides the ability to work with state information systems to any software through open data exchange formats and, which is extremely important, involves the transfer of all electronic documents that are part of the information model of a capital construction object.

\section{Materials and methods}

* Corresponding author: chelyshkovpd@mgsu.ru 
Here it is necessary to define what exactly can be understood by the term "information model" in the context of data exchange. The information model of a capital construction object consists of electronic documents, which include digital information models (DIM), that is, an object-oriented model that digitally represents the physical, functional and other characteristics of an object (or its individual parts) as a set of information-rich elements. But in addition to DIM, the information model includes other electronic documents: contracts, technical specifications and other documents provided for, in particular, by the Decree of the Government of the Russian Federation No. 87 dated February 16, 2008 "On the composition of sections of project documentation and requirements for their content" (the last changes to which entered into force on October 1, 2020). At the same time, if the DIM is represented by "live" (that is, available for machine reading and editing) digital data, then other elements can be presented in various formats, transmitting them "like a picture". This means that if the DIM can be represented in the form of an XML document by comprehensible methods, then documents presented in a different way can be partially (or completely) described in the XML format and only after that are included in the data exchange process. So, it seems correct to single out 3 generations of information models in terms of their maturity with respect to participation in the established process of data exchange (Fig. 1).

Information Model ver. 1.0 (until 2021)

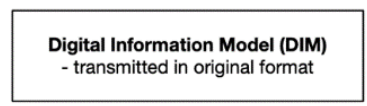

Digital Information Model (DIM)
Information Model ver. 2.0 (from 2021)

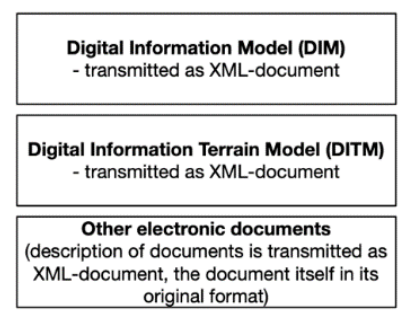

Information Model ver. 3.0 (from 2025)

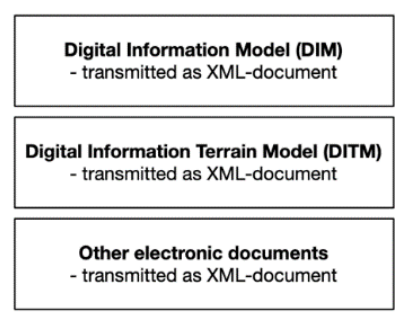

Fig. 1. Scheme of the enlarged generational model of information models

The first generation is information models containing exclusively DIM. Such models are typically sent in native format (in development environment format) or in open IFC format. Thus, there is a transfer of information models to the bodies of state expertise and government customers. The second generation is information models that correspond to the composition stipulated in, but only partially described in XML documents other than DIM. And the third generation is information models containing exclusively "live" digital data. Such models do not require the application of documents "as pictures" and in fact provide a transition from document flow to DATA flow, that is, to work with data, not with documents. At the same time, already today there is a technical and technological opportunity for the formation and work with information models of the third generation, but such a transition is fully possible only by forming a completely "ecosystem" of information systems that generate, receive and process "live" digital data. For example, the issuance of technical specifications should take place in the format of an XML document, which in this case can be integrated into the information model, and hence into computer-aided design, automated State construction supervision, etc. In this regard, it is advisable to provide for a phased transition from the current situation (1st generation) to a promising one (3rd generation) through an intermediate stage, which can be technically implemented from 2021. 
In this case, it is necessary to highlight the main parameters of electronic documents not related to DIM. Such parameters should be described in XML format, while the full text of the document will be available "as a picture". Such work was carried out and implemented in Appendix A of amendments to the Code of Rules 333.1325800.2017 "Rules for the formation of an information model of objects at various stages of the life cycle". A fragment of such requirements concerning one of the documents is given below in Table 1 .

Table 1. Requirements for the presentation of non-DIM documents as part of the information model in XML format

\begin{tabular}{|l|l|l|l|}
\hline $\begin{array}{l}\text { Name of the } \\
\text { electronic document }\end{array}$ & Attribute name & Data type & $\begin{array}{l}\text { Link to regulatory } \\
\text { source }\end{array}$ \\
\hline \multirow{5}{*}{$\begin{array}{l}\text { Contract for the } \\
\text { implementation of } \\
\text { architectural and } \\
\text { construction design, } \\
\text { including design } \\
\text { assignment }\end{array}$} & Subject of the contract & Text & $\begin{array}{l}\text { art. 432, N 190-FL } \\
\text { from 29.12.2004 }\end{array}$ \\
\cline { 2 - 4 } & $\begin{array}{l}\text { Unique identification } \\
\text { number (UIN) of the } \\
\text { contract }\end{array}$ & Text & $\begin{array}{l}\text { art. 432, N 190-FL } \\
\text { from 29.12.2004 }\end{array}$ \\
\cline { 2 - 4 } & Number of contract & Text & $\begin{array}{l}\text { art. 432, N 190-FL } \\
\text { from 29.12.2004 }\end{array}$ \\
\cline { 2 - 4 } & Contract date & Text & $\begin{array}{l}\text { art. 432, N 190-FL } \\
\text { from 29.12.2004 }\end{array}$ \\
\cline { 2 - 4 } & Participant 1 & Text & $\begin{array}{l}\text { art. 432, N 190-FL } \\
\text { from 29.12.2004 }\end{array}$ \\
\cline { 2 - 4 } & Participant 2 & Text & $\begin{array}{l}\text { art. 432, N 190-FL } \\
\text { from 29.12.2004 }\end{array}$ \\
\cline { 2 - 4 } & $\begin{array}{l}\text { The amount of the } \\
\text { contract }\end{array}$ & Text & $\begin{array}{l}\text { art. 432, N 190-FL } \\
\text { from 29.12.2004 }\end{array}$ \\
\cline { 2 - 4 } & Contract text & Monetary & $\begin{array}{l}\text { art. 432, N 190-FL } \\
\text { from 29.12.2004 }\end{array}$ \\
\hline
\end{tabular}

To ensure data exchange processes for information models of the 2nd generation, it is necessary to form a set of XML schemas. We are talking about such models as:

- Engineering survey model

- Conceptual model

- Design model

- Construction model

- Executive model

- Operational model

- Demolition and disposal model

The engineering survey model is formed at the engineering survey stage in order to form aggregate initial data for planning the future capital construction object. Allows you to make a comprehensive analysis of the territory, environment and underground space in order to determine the construction technology and possible restrictions for construction. The model is formed based on the data of the performed engineering surveys.

The conceptual model is formed at the stage of investment justification. The purpose of the development of the model is to form the technical and economic indicators of the object and provide the possibility of their analysis for making a decision on the feasibility of building the object. The model is formed taking into account the data of the Engineering Survey Model.

The design model is formed at the stage of Architectural and construction design. One of the goals of forming the design model is the submission and transfer of the capital 
construction object IM, containing the design model, including estimates for the construction of a capital construction facility, for the examination of design documentation. The model is formed taking into account the data of the Engineering Survey Model and the Conceptual Model.

The construction model is formed at the stage of Construction or Reconstruction, or Overhaul as a form of detailed planning of construction production. The construction model must fulfill the functional requirements for the working documentation. The model is formed on the basis of the Design Model, which has a positive expert opinion as part of the corresponding Information Model.

The executive model is formed at the stage of Construction or Reconstruction, or Overhaul in order to generate complete information about the object based on the results of construction (or reconstruction, or overhaul) and contains the data necessary as initial data for the formation of an operational model and for subsequent planning of reconstruction, overhaul repair, demolition and disposal. The model contains data on the conformity of the results of construction work to the Design Model. The model is formed on the basis of the Design model and the "As built" model.

The operational model is formed at the Operation stage in order to ensure the formation and decision-making processes for planning the operation technology, planning regulated maintenance and managing changes in the capital construction object during the operation stage. At the same time, the Operational Model together with the Executive Model serve as the basis for the formation of initial data and information modeling for reconstruction, overhaul, subsequent demolition and disposal of a capital construction object. The model is formed on the basis of the Executive model. In the absence of the Executive Model, the Operational Model is formed based on the results of the survey of the capital construction facility.

The demolition and utilization model is formed at the Demolition and utilization stage in order to plan construction production in terms of dismantling works and land reclamation. The model is formed on the basis of the Operational Model. In the absence of an Operational Model, the Demolition and Utilization Model is formed based on the results of a survey of the capital construction facility.

The diagram of the plan for the development of XML-schemas that provide information exchange processes regarding the considered models is shown in Table 2.

Table 2. An enlarged principle for the development of XML schemas according to the Information Model ver. 2.0

\begin{tabular}{|c|c|c|c|}
\hline \multirow[b]{2}{*}{ № } & \multirow[b]{2}{*}{ Stage } & \multicolumn{2}{|c|}{ XML-schemas } \\
\hline & & $\begin{array}{l}\text { Buildings and } \\
\text { constructions }\end{array}$ & Linear Objects \\
\hline \multirow{2}{*}{1} & \multirow{2}{*}{ Engineering Survey } & \multicolumn{2}{|c|}{$\begin{array}{c}\text { XML-schema of Information Model of Engineering } \\
\text { Survey }\end{array}$} \\
\hline & & \multicolumn{2}{|c|}{$\begin{array}{c}\text { XML-schema of expertise of Information Model of } \\
\text { Engineering Survey }\end{array}$} \\
\hline \multirow[t]{3}{*}{2} & \multirow[t]{3}{*}{$\begin{array}{l}\text { Investment } \\
\text { Justification }\end{array}$} & $\begin{array}{c}\text { XML-schema of the } \\
\text { conceptual Information } \\
\text { Model of buildings and } \\
\text { structures }\end{array}$ & $\begin{array}{l}\text { XML-schema of the } \\
\text { conceptual Information } \\
\text { Model of linear objects }\end{array}$ \\
\hline & & \multicolumn{2}{|c|}{ Optional XML-schemas of conceptual process models } \\
\hline & & \multicolumn{2}{|c|}{ XML-schema of expertise of investment justification } \\
\hline 3 & $\begin{array}{l}\text { Architectural and } \\
\text { construction design }\end{array}$ & $\begin{array}{c}\text { XML-schema of the } \\
\text { project Information Model }\end{array}$ & $\begin{array}{l}\text { XML-schema of the } \\
\text { project Information }\end{array}$ \\
\hline
\end{tabular}




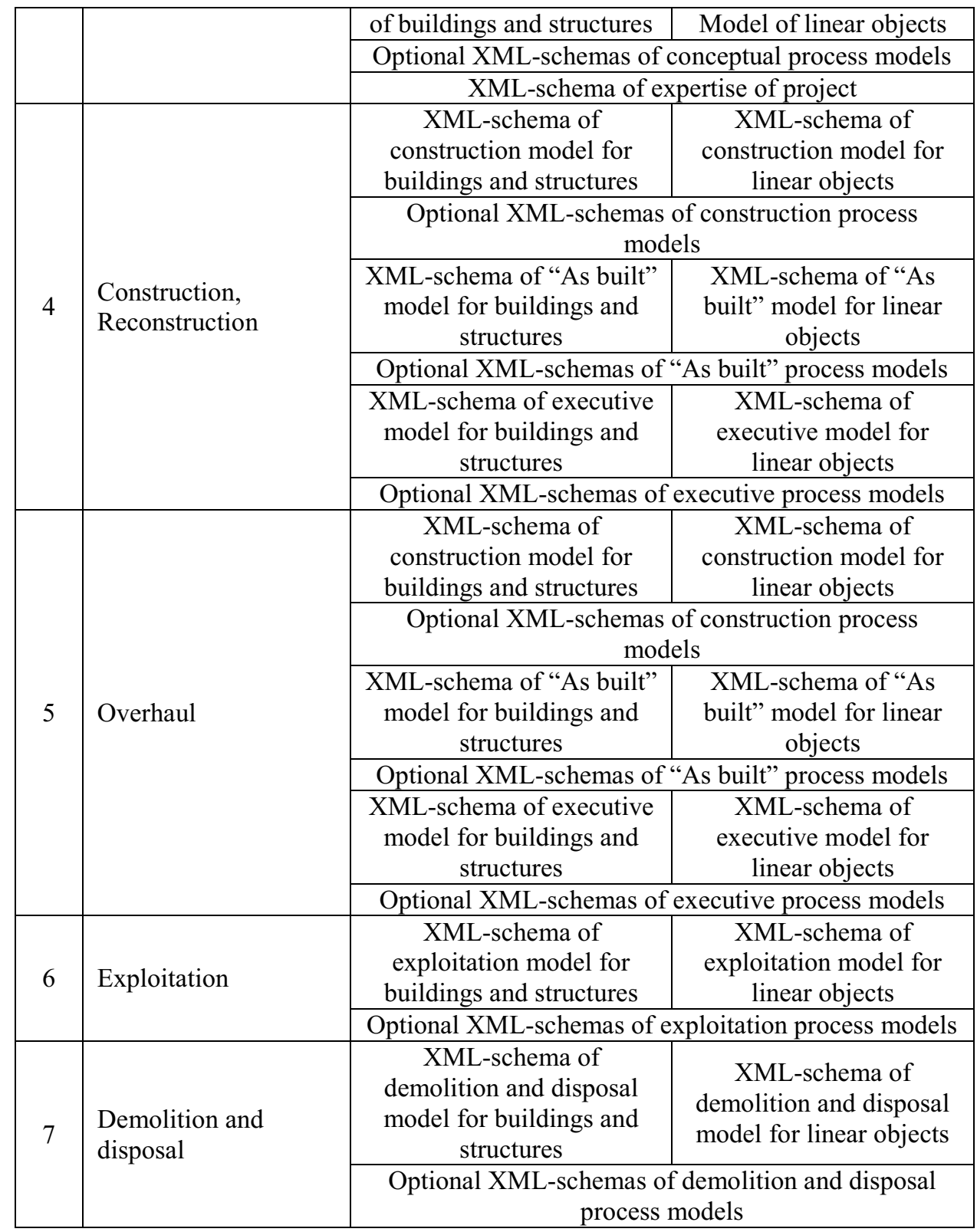

The developed XML schemas will provide the processes of formation of information models transmitted to state information systems and their verification according to uniform rules, which is necessary for the functioning of any information system.

Moreover, the set of XML schemas has the following structure. There is a root schema that implements the general requirements for the description of elements and attributes of the information model, based on the XML schema of the IFC format developed by Building Smart and extended with some additional elements. And there are root schema extensions that describe the requirements for describing attributes in accordance with the regulatory and technical documents of the Russian Federation, in particular, in accordance with the new edition of the Code of Rules 333.1325800.2017 "Rules for the formation of an 
information model of objects at different stages of the life cycle". The XML schema set is shown in Fig. 2
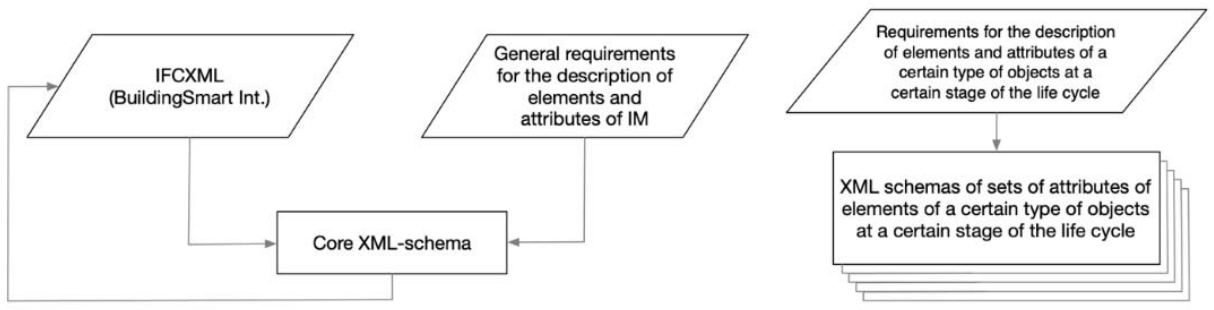

Fig. 2.A set of XML schemas for the implementation of information interaction using an information model of a certain type at a certain stage of the life cycle.

The set of XML schemas formed in this way ensures the verification of the information model, that is, establishing the correspondence of the composition of the attribute and geometric data included in the digital information model to a certain set of requirements. The algorithm for verifying the information model of a capital construction object using XML schemas is shown in Fig. 3.

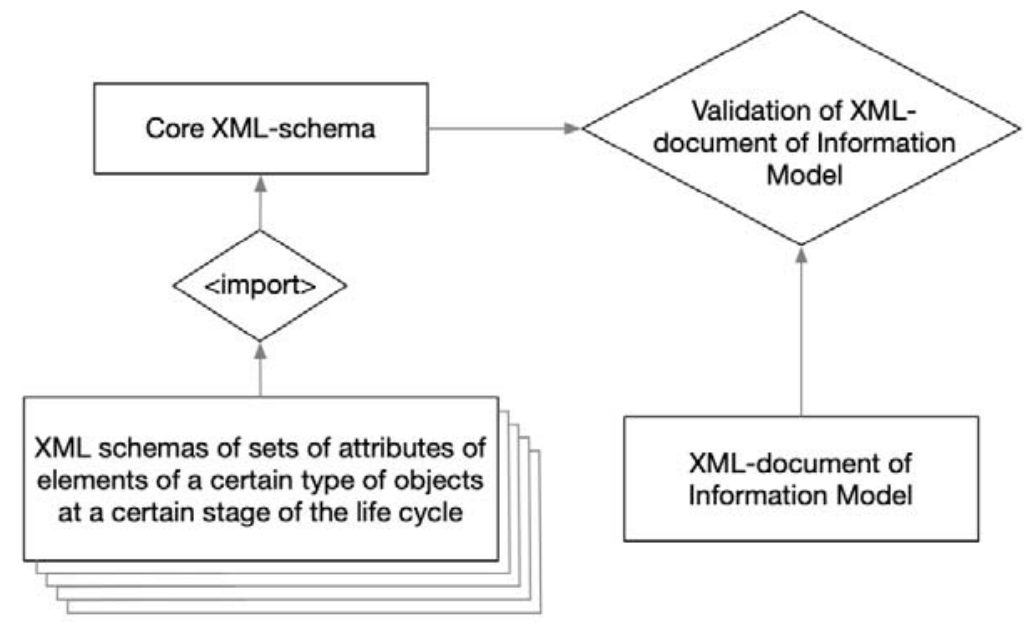

Fig. 3. Algorithm for verifying the information model of a capital construction object using XML schemas

In practice, for the implementation of information interaction between the participants of the investment and construction project, a scheme is used with the use of several information systems that provide a complete (quantitative) and reliable (qualitative) conversion of the source data formats into an open XML format. This algorithm is summarized in Figure 4. 


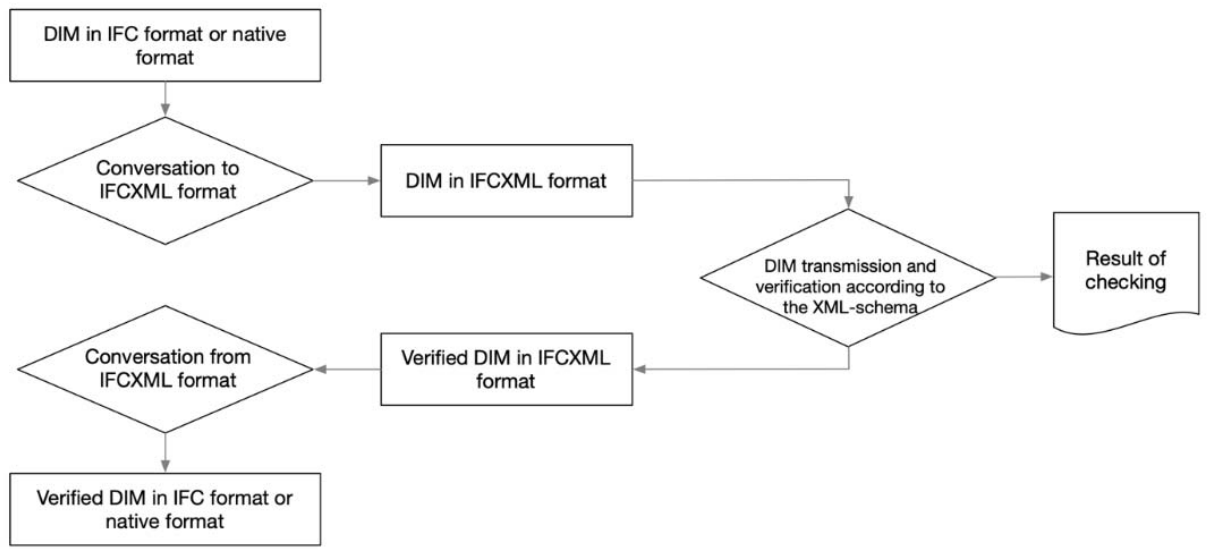

Fig. 4. Diagram of the communication process

To perform the "Conversion to IFCXML" process and the "Conversion from IFCXML" process, you must use the functions of the software for working with digital information models (CIM), or special converters. The following is an analysis of the software in order to determine the possibility of implementing inter-format data conversion (Table 3).

Table 3. Analysis of the software in order to determine the possibility of implementing inter-format data conversion

\begin{tabular}{|l|l|l|c|c|c|c|}
\hline Softwarename & Producer & $\begin{array}{c}\text { Ver- } \\
\text { sion }\end{array}$ & $\begin{array}{c}\text { IF } \\
\text { C }\end{array}$ & $\begin{array}{c}\text { IFC taking } \\
\text { into account } \\
\text { the } \\
\text { requirement } \\
\text { s of SP 333 }\end{array}$ & $\begin{array}{c}\text { IFCXM } \\
\text { L }\end{array}$ & $\begin{array}{c}\text { IFCXML } \\
\text { taking } \\
\text { into } \\
\text { account } \\
\text { the } \\
\text { requirem } \\
\text { ents of } \\
\text { SP 333 }\end{array}$ \\
\hline Revit & Autodesk & $\begin{array}{l}202 \\
0\end{array}$ & E/I & E/I & E & E \\
\hline Navisworks & Autodesk & & E/I & E/I & E & - \\
\hline Civil 3D & Autodesk & & E/I & E/I & E & - \\
\hline ArchiCAD & Graphisoft & 24 & E/I & I & E & - \\
\hline SketchUp & Trimble & & E/I & I & E & - \\
\hline Allplan & $\begin{array}{l}\text { AllplanGmb } \\
\text { H }\end{array}$ & & E/I & I & E & - \\
\hline TeklaStructures & Trimble & & E/I & I & E & - \\
\hline $\begin{array}{l}\text { Tekla Model } \\
\text { Sharing }\end{array}$ & Trimble & & I & I & - & - \\
\hline $\begin{array}{l}\text { Trimble } \\
\text { Connect }\end{array}$ & Trimble & & I & I & - & - \\
\hline BimVision & $\begin{array}{l}\text { Datacomp } \\
\text { Sp. z o.o. }\end{array}$ & & E/I & I & - & - \\
\hline Renga & RengaSoftwa & & E/I & I & E & - \\
\hline NanoCad & JSC & & E/I & I & E & - \\
\hline
\end{tabular}




\begin{tabular}{|l|l|c|c|c|c|c|}
\hline & «Nanosoft» & & & & & \\
\hline Solibri & SolibriInc & & I & I & - & - \\
\hline SolidWorks & $\begin{array}{l}\text { DassaultSyst } \\
\text { èmes }\end{array}$ & & E/I & I & E & - \\
\hline CATIA & $\begin{array}{l}\text { DassaultSyst } \\
\text { èmes }\end{array}$ & & E/I & I & E & - \\
\hline MagiCAD & $\begin{array}{l}\text { MagiCADGr } \\
\text { oup }\end{array}$ & & E/I & I & E & - \\
\hline AECOsim & Bentley & & E/I & I & E & - \\
\hline LIRA-SAPR & Lira Sapr & & E/I & I & E & - \\
\hline
\end{tabular}

Note: $E$ - export, I - import.

From the above analysis it can be seen that today the software for working with CIM does not have the functions of converting to the IFCXML format and reverse converting. Also, it was not possible to identify an available converter that implements the conversion to the IFCXML format, taking into account the requirements of the updated edition of SP 333. Based on the above, it is necessary to undertake joint work with software manufacturers to work with digital information models (DIM), or special converters for software modernization in accordance with the requirements set out in this study.

\section{Discussion}

Next, we will consider the scenario of using this technology for the implementation of information interaction with the field of urban planning activities. The next and partly isolated stage in the development of information modeling is the technology of information modeling of cities (CIM). CIM is a complex of technologies and diverse data that combines the comprehensiveness of geographic information systems (GIS) and BIM detail in threedimensional space, collecting information on the natural landscape, buildings and infrastructure.

At the moment, the CIM concept is faced with the problem of integration and convergence with detailed BIM. And if they learned how to cope with the import of geometric parameters of capital construction objects into GIS [18,19], then nothing has been resolved with the import of object data: there is no working and proven methodology for integrating BIM data into CIM, the format for transferring this data has not been defined.

Today there are many [20] formats for presenting such data about capital construction objects: for example, they include the well-known IFC, as well as CityGML, LandXML, etc. In the conversation about the development of CIM, in the opinion of the authors, we cannot choose any one format, since we immediately find ourselves in the limitations of this format. Therefore, it is necessary to strive for the development of open formats obviously, by the forces of professional communities - and formats that should be simple to begin with.

Considering all the prerequisites, we can recommend the approach presented in this article for implementation as one of the priority formats for data exchange in the implementation of urban planning activities using GIS.

\section{Conclusion}

The approach considered in this article to the exchange of digital data in information systems for ensuring urban planning activities allows for a phased transition to the 
implementation of an information system for supporting the full life cycle of capital construction projects, providing the ability to use any software tools that support open data exchange technologies. According to the authors of the article, the mechanism of information interaction proposed in the work can be extended to the CIM model, which will have a positive effect on the development of this concept.

This work was financially supported by the Ministry of Science and Higher Education of the Russian Federation (\#SP-4555.2018.1).

\section{References}

1. The Town Planning Code of the Russian Federation dated December 29, 2004 No. 190-FZ.

2. Federal Law of the Russian Federation "On Electronic Signature" dated 06.04.2011 No. 63-FZ.

3. Federal Law of the Russian Federation "On Information, Information Technologies and Information Protection" dated July 27, 2006 No. 149-FZ.

4. Federal Law of March 20, 2011 No. 41-FZ "On the Federal State Information System for Territorial Planning".

5. Federal Law of 30.12.2015 No. 431-FZ "On Geodesy, Cartography and Spatial Data”.

6. Order of the President of the Russian Federation dated May 18, 2017 No. 163-rp "Plan for the transition to the use of domestic geoinformation technologies".

7. Decree of the Government of the Russian Federation of March 26, 2019 No. 319 "On a unified information system for housing construction".

8. Decree of the Government of the Russian Federation of 08.06.2011 No. 451 "On the infrastructure providing information and technological interaction of information systems used to provide state and municipal services in electronic form".

9. Decree of the Government of the Russian Federation of 12.04.2012 No. 289 "On the federal state information system of territorial planning".

10. Decree of the Government of the Russian Federation dated 09.06.2006 No. 363 "On information support of urban planning activities".

11. Decree of the Government of the Russian Federation dated July 24, 2017 No. 878 "On the procedure for forming a unified state register of expert examination conclusions of design documentation for capital construction projects and amending the Resolution of the Government of the Russian Federation dated March 05, 2007 No. 145".

12. Decree of the Government of the Russian Federation dated 05.03.2007 No. 145 "On the procedure for organizing and conducting state expertise of project documentation and the results of engineering surveys".

13. Decree of the Government of the Russian Federation of 23.09.2016 No. 959 "On the federal information system of pricing in construction".

14. Resolution of the Government of the Russian Federation of April 21, 2018 No.482 "On the state information system" Typical cloud solution for the automation of control (supervisory) activities".

15. Decree of the Government of the Russian Federation of 15.04.2014 No. 316 "On approval of the state program of the Russian Federation" Economic development and innovative economy".

16. Decree of the Government of the Russian Federation of 28.11.2011 No. 977 "On the 
federal state information system" A unified system of identification and authentication in the infrastructure that provides information technology interaction of information systems used to provide state and municipal services in electronic form. "

17. Decree of the Government of the Russian Federation of September 15, 2020 No. 1431 "On approval of the Rules for the formation and maintenance of the information model of a capital construction object, the composition of information, documents and materials included in the information model of a capital construction object and presented in the form of electronic documents, and requirements for the formats of these electronic documents. documents, as well as amending clause 6 of the Regulation on the implementation of engineering surveys for the preparation of design documentation, construction, reconstruction of capital construction facilities ".

18. E. Shirinyan, BIM in Urban Planning. In search of a common pattern. URL: https://prosapr.blogspot.com/2016/09/bim_17.html (date of access: 18.09.2020).

19. E. Shirinyan, From BIM to CIM. URL: https://isicad.ru/ru/articles.php?article_num=19872 (date of access: 24.09.2020).

20. OGC Standards. URL: https://www.ogc.org/docs/is (date of access: 04.10.2020). 